\title{
Personal $\mathrm{NO}_{2}$ and Volatile Organic Compounds Exposure Levels are Associated with Markers of Cardiovascular Risk in Women in the Cape Town Region of South Africa
}

\author{
Frans Everson ${ }^{1}{ }^{(}$, Patrick De Boever ${ }^{2,3}, * \mathbb{1}$, Tim S. Nawrot ${ }^{3}$, Nandu Goswami ${ }^{4}$, \\ Mashudu Mthethwa ${ }^{1}$, Ingrid Webster ${ }^{1}$, Dries S. Martens ${ }^{3}$, Nyiko Mashele ${ }^{1}$, Sana Charania ${ }^{1}$, \\ Festus Kamau ${ }^{1}$ (D) and Hans Strijdom ${ }^{1}$ (D) \\ 1 Division of Medical Physiology, Faculty of Medicine and Health Sciences, Stellenbosch University, \\ P.O. Box 241, Cape Town 8000, South Africa \\ 2 Health Unit, Flemish Institute for Technological Research (VITO), 2400 Mol, Belgium \\ 3 Centre for Environmental Sciences, Hasselt University, 3590 Diepenbeek, Belgium \\ 4 Division of Physiology, Otto Loewi Research Center of Vascular Biology, Immunity and Inflammation, \\ Medical University of Graz, 8036 Graz, Austria \\ * Correspondence: patrick.deboever@vito.be; Tel.: +32-14-335145
}

Received: 18 May 2019; Accepted: 15 June 2019; Published: 28 June 2019

\begin{abstract}
Exposure to ambient $\mathrm{NO}_{2}$ and benzene, toluene ethyl-benzene and $\mathrm{m}+\mathrm{p}$ - and o-xylenes (BTEX) is associated with adverse cardiovascular effects, but limited information is available on the effects of personal exposure to these compounds in South African populations. This 6-month follow-up study aims to determine 7-day personal ambient $\mathrm{NO}_{2}$ and BTEX exposure levels via compact passive diffusion samplers in female participants from Cape Town, and investigate whether exposure levels are associated with cardiovascular risk markers. Overall, the measured air pollutant exposure levels were lower compared to international standards. $\mathrm{NO}_{2}$ was positively associated with systolic and diastolic blood pressure (SBP and DBP), and inversely associated with the central retinal venular equivalent (CRVE) and mean baseline brachial artery diameter. o-xylene was associated with DBP and benzene was strongly associated with carotid intima media thickness (cIMT). Our findings showed that personal air pollution exposure, even at relatively low levels, was associated with several markers of cardiovascular risk in women residing in the Cape Town region.
\end{abstract}

Keywords: air pollution; nitrogen dioxide; BTEX; cardiovascular risk; South Africa

\section{Introduction}

Ambient air pollution is a global health concern and is associated with numerous adverse health effects including cardiovascular disease (CVD) [1-3]. The health effects of ambient air pollution are mostly attributable to small particles and chemically reactive compounds with pro-oxidative potential [4-7]. Previous reports have suggested that the adverse cardiovascular effects associated with air pollution exposure may be due to autonomic nervous system dysregulation of vascular tone and heart rates [8,9], and pro-atherosclerotic processes such as oxidative stress, inflammation, and endothelial dysfunction [9-11]. Although several chemical components present in ambient air have been implicated in adverse cardiovascular outcomes (e.g., nitrogen and carbon oxides, and particulate matter (PM)), the specific contributions and underlying mechanisms of exposure to individual components are not well understood $[1,12,13]$. 
The World Health Organization (WHO) has identified gaseous pollutants such as $\mathrm{NO}_{2}$ and $\mathrm{PM}$ with a diameter of $\leq 2.5 \mu \mathrm{m}\left(\mathrm{PM}_{2.5}\right)$ as the air pollutants that are most dangerous to public health [14]. Other gaseous pollutants in ambient air include polycyclic aromatic hydrocarbons (PAHs) such as benzene, toluene ethyl-benzene and $\mathrm{m}+\mathrm{p}$ - and o-xylenes (BTEX) [15-18]. These gaseous pollutions are mostly produced as a result of the incomplete combustion of fossil fuels during industrial, vehicle, and household activities and are therefore considered a good proxy for general air quality and combustion-related emissions [15-18]. Due to their small molecular size (molecular diameter: $<0.1 \mathrm{~nm}$ ), these ambient air pollutants are able to passively enter the blood circulation during respiration (predominant route of exposure) and disseminate throughout the body, even at the cellular and nuclear levels where they can exert their harmful effects $[1,7,19]$.

Reports on air pollution levels and related health effects are mostly based on data from the developed world, while the situation in developing countries remains under-reported [20-23]. A recently published systematic review by Katoto et al. (2019) highlighted the lack of air pollution data from the sub-Saharan Africa (SSA) region [23]. The authors identified only 23 published research articles from SSA (of which 14 were from South Africa) that reported on the health effects associated with ambient air pollution. It is evident, however, that data from personal quantitative exposure measurements are under-reported, and none of these studies investigated the effects of air pollution on vascular health and function. The review furthermore reported on studies demonstrating urban air pollution levels of up to 10-20 times greater than recommended WHO standards in some SSA locations [23]. In light of these findings and knowledge gaps, the overarching aims of the current study were to: (1) determine current levels of personal $\mathrm{NO}_{2}$ and BTEX exposure during two 1-week time periods in a repeated-measurements study (6-month follow-up) of apparently healthy women residing in the Cape Town region of South Africa, and (2) determine whether current levels of personal $\mathrm{NO}_{2}$ and BTEX exposure are associated with markers of cardiovascular risk, including blood pressure (systolic blood pressure (SBP) and diastolic blood pressure (DBP), respectively), flow-mediated vasodilatation (FMD), retinal blood vessel widths, and carotid intima media thickness (cIMT).

\section{Materials and Methods}

\subsection{Study Ethics, Design, and Population}

The current study formed part of a larger parent study called EndoAfrica and participants for the current study were recruited from the healthy control study group of the parent study [24]. Ethical clearance for the current study was obtained from the Health Research Ethics Committee of Stellenbosch University (ethics reference number: S16/07/114), which subscribes to the principles of the Helsinki Declaration (1975). The study followed a non-interventional, longitudinal (6-month follow-up) cohort design. Healthy volunteering female participants of mixed ancestry were randomLy recruited for the first assessment visit (baseline) from September 2016 to August 2017 at primary health care clinics in the Cape Town region. All participants were from the residential areas of Elsies River, Bishop Lavis, and Ravensmead. All 6-month assessment visits (follow-up) were completed by February 2018. Qualified research nurses recruited, screened, and obtained informed consent from all participants. Participants who were $<18$ years of age, with human immunodeficiency virus/acquired immunodeficiency syndrome (HIV/AIDS; confirmed with a rapid HIV test; SD Bioline HIV 1/2 3.0 immunochromatographic test kit; Standard Diagnostics, Republic of Korea), with current tuberculosis (confirmed from participant clinic files), pregnant (confirmed with a pregnancy test), $<3$ months post-partum, of poor health, or with a current or previous history of heart disease were excluded.

\subsection{Air Quality and Temperature Monitoring}

Each participant was equipped with a Gradko rapid $\mathrm{NO}_{2}$ device (Gradko International Ltd., Winchester, UK), a Radiello ${ }^{\mathrm{TM}}$ BTEX passive diffusion sampler (Sigma-Aldrich Inc., MO, USA), and an ACR SmartButton ${ }^{\circledR}$ temperature logger (ACR Systems Inc., Surrey, B.C., Canada) placed in the 
external mesh pocket of a backpack (Figure A1a-d). The mesh pocket allowed for unrestricted continuous contact with ambient indoor and outdoor temperature and air (Figure A1e). Although previous studies have measured personal sampling within a $30 \mathrm{~cm}$ hemisphere from the face $[25,26]$, personal exposure for the current study was measured within a hemisphere of 50 to $60 \mathrm{~cm}$ from the face (Figure A1f). Participants carried the backpack at all times (except during periods of sleep and bathroom use when the backpack was placed next to their beds) for a 7-day period. Temperature was recorded continuously at 30-minute intervals while the $\mathrm{NO}_{2}$ and BTEX samplers allowed for continuous passive diffusion and accumulation of $\mathrm{NO}_{2}$ and BTEX. Following continuous 7-day measurements, participants returned for the first assessment visit, during which the backpacks were collected, data were extracted from the temperature loggers via ACR TrendReader ${ }^{\circledR}$ software (ACR Systems Inc., Surrey, B.C., Canada), and the average temperature $\left({ }^{\circ} \mathrm{C}\right)$ for the 7 -day period was recorded. Once collected, the $\mathrm{NO}_{2}$ and BTEX samplers were sealed, stored at $4{ }^{\circ} \mathrm{C}$ and sent for quantification according to the manufacturer's protocol.

$\mathrm{NO}_{2}$ samplers were sent to Gradko International Ltd. laboratories (United Kingdom Accreditation Services (UKAS) accredited)) for quantification according to UKAS method GLM 7 [27]. A calibration curve (blank with only deionized water, 15, 30, 60, $90120 \mu \mathrm{g} / \mathrm{mL}$ ) was prepared from a standard nitrate solution $\left(1 \mathrm{~g} / \mathrm{L}\right.$ nitrite ion $\left.\left(\mathrm{NO}_{2}^{-}\right)\right)$. The color reagent was prepared as previously described [28] and used in a sample:sulphanilamide solution:N-1 (naphthyl-1) ethylene diamine dihydrochloride solution (NEDD) ratio of 1:2:2 (0.003 $\mathrm{g}$ NEDD per $1 \mathrm{~g}$ sulphanilamide). After sample elution (preparation: $20 \%$ triethanolamine (TEA) solution/ $80 \%$ deionized water), $\mathrm{NO}_{2}$ concentrations were determined via chemiluminescence ultraviolet (UV) spectrophotometry (UVS04 Camspec M550; Spectronic Camspec Ltd., Leeds, UK). Calibration standards and linearity checks were used to calibrate the spectrophotometer, and mid-range and zero standards were analyzed at intervals throughout the sequence for quality assurance. The calibration curve was used to calculate the $\mathrm{NO}_{2}{ }^{-}$concentration for each sample. The ambient $\mathrm{NO}_{2}$ concentration was calculated from $\mathrm{NO}_{2}{ }^{-}$concentrations and expressed as $\mu \mathrm{g} / \mathrm{m}^{3}$ [29].

BTEX samplers were sent to the Flemish Institute for Technology and Research (VITO; Mol, Belgium) for quantification as previously described [30,31]. BTEX samples were extracted from exposed samplers by means of elution in the Radiello ${ }^{\mathrm{TM}}$ glass tube containing the cartridge ( $2 \mathrm{~mL}$ carbon disulphide ( $\mathrm{CS}_{2}$; Sigma-Aldrich, MO, USA) and $12.5 \mu \mathrm{L}$ 2-fluorotoluene internal standard (Sigma-Aldrich, MO, USA)). The tube was stirred for 30 minutes on a rotational shaker. BTEX quantification was performed by means of gas chromatography (Thermo Trace) and a mass spectrometer (Thermo DSQ II with helium as carries gas (a constant flow of $1 \mathrm{~mL} / \mathrm{min}$ )). A cross-bond diphenyl/dimethylpolysiloxane column (RTX $502.2 ; 0.25 \mathrm{~mm}$ by $30 \mathrm{~m}$ ) with a $1.4 \mu \mathrm{m}$-thick film was used for sample separation (temperature program: $35^{\circ} \mathrm{C}$ for 5 minutes, $14{ }^{\circ} \mathrm{C}$ /minute increment until $245^{\circ} \mathrm{C}$ ). Equipment calibration was performed by injecting the standard solution (benzene, ethyl-benzene, toluene, m-xylene, p-xylene, and o-xylene in $\mathrm{CS}_{2}$ (Sigma-Aldrich, MO, USA)) at 0.03 to $30 \mu \mathrm{g} / \mathrm{g}$ before analysis. Sample concentrations were calculated from chromatograms using a standard curve. The limit of detection (LOD) was calculated as 3.3 (standard deviation (SD) of areas/slope). Samples with conc. $<\mathrm{LOD}$ were not presented. Results were expressed as average $\mathrm{NO}_{2}$ and BTEX exposure concentration $\left(\mu \mathrm{g} / \mathrm{m}^{3}\right)$ for the 7 -day measuring period. The same procedure was followed for the 6-month follow-up visits.

\subsection{Study Endpoints}

\subsubsection{Health Questionnaire and Anthropometric Measurements}

At each visit, participants completed a comprehensive questionnaire to collect data on age, smoking status (defined as smoking or non-smoking), socioeconomic information (including employment status defined as either unemployed, part-time employed, or full-time employed), and lifestyle (hours of sleep at night defined as 1 to 3 hours, between 3 and 6 hours, 6 to 9 hours, and $>9$ hours). Qualified research 
nurses measured fasting blood glucose levels (mmol/L) by finger prick (Gluco Plus ${ }^{\mathrm{TM}}$, Cipla DIBCARE, Bellville, South Africa) and collected fasting blood and mid-stream urine samples. Cardiovascular measurements included SBP and DBP (calculated as an average of 3 measurements at 5-minute intervals on the left arm and expressed in $\mathrm{mmHg}$ ) via an Omron $\mathrm{M} 6$ automatic digital blood pressure monitor (Omron Healthcare, Kyoto, Japan). Hypertension was defined as either SBP of $\geq 140 \mathrm{mmHg}$ or DBP of $\geq 90 \mathrm{mmHg}$, based on the South African Hypertension Society guidelines [32]. Body mass (kg) was determined on an electronic scale, and height $(\mathrm{cm})$ was decided by means of a stadiometer. Finally, body-mass index (BMI) was expressed as $\mathrm{kg}$ body weight $/ \mathrm{m}^{2}$ height.

\subsubsection{Biochemical Analysis}

Fasting whole blood was collected in blood collection tubes (SGVac, The Scientific Group (Pty) Ltd.; Milnerton, Western Cape, SA). Serum was extracted from whole blood samples and stored at $-80^{\circ} \mathrm{C}$. Serum samples were analyzed by the South African National Health Laboratory Service (NHLS; Tygerberg Hospital, Cape Town, South Africa), a South African National Accreditation System (SANAS)-accredited laboratory, for high-sensitivity C-reactive protein (hsCRP) levels by means of an IMMAGE ${ }^{\circledR}$ Immunochemistry Systems and Calibrator 5 Plus assay kit (Beckman Coulter, Inc., CA, USA). This specific chemiluminescence analysis was based on the highly sensitive Near Infrared Particle Immunoassay rate methodology where anti-CRP antibody-coated particles bind to the CRP in the serum sample resulting in an insoluble aggregate formation and turbidity. Samples were prepared for analysis by adding $4.5 \mu \mathrm{L}$ serum sample, $42 \mu \mathrm{L}$ antibody-coated particles (particle-bound goat and mouse anti-CRP antibody), $125 \mu \mathrm{L}$ buffer 4 and $42 \mu \mathrm{L}$ diluent (sodium azide: $<0.1 \%(w / w)$ ). The hsCRP concentration was determined automatically as the rate of aggregate formation (directly proportional). For the purposes of this study, increased hsCRP was defined as hsCRP levels of $>3 \mathrm{mg} / \mathrm{L}$ based on previous reports suggesting that hsCRP levels above this cut-off value are associated with increased cardiovascular risk [33].

Mid-stream urine samples were obtained at each visit, placed on ice and immediately delivered to the NHLS for the quantification of urinary creatinine levels by means of chemiluminescence (cobas ${ }^{\circledR}-\mathrm{c}$ analyzer and CREP2 kit; Roche Diagnostics, Basel, Switzerland). The principal of the method was based on the enzymatic formation of hydrogen peroxide (catalyzed by peroxidase) that reacted with 2,4,6-triiodo-3-hydroxybenzoic acid for quinone imine chromogen. Creatinine levels were determined by the color intensity of the quinone imine chromogen (directly proportional).

\subsubsection{Urinary Analysis of Metabolites of Volatile Organic Compounds}

Additional mid-stream urine samples were stored at $-80^{\circ} \mathrm{C}$ and sent to VITO (Mol, Belgium) for level determinations of the following urinary metabolites: N-acetyl-S-(3-hydroxypropyl)-L-cysteine (HPMA; a marker of acrolein exposure [34]), N-acetyl-s-(phenyl)-L-cysteine (PMA; a marker of benzene exposure [35]), N-acetyl-s-(benzyl)-L-cysteine (BMA; a marker of toluene exposure [36]), trans,trans-muconic acid (MU; a marker of benzene exposure [35]), and 3+4-methylhippuric acid (3+4MHA; a marker of o-, m-, and p-xylene exposure [37]). Samples were prepared using $10 \mu \mathrm{L}$ urine, $25 \mu \mathrm{L}$ mixed internal standard $(2000 \mathrm{ng} / \mathrm{mL}$ in methanol:water(1:1, v:v)) MU-d4 and 3 (Santa Cruz Biotechnology, TX, USA), and 4 MHA-d7 (Toronto research chemicals Inc., ON, Canada) with $465 \mu \mathrm{L} \mathrm{1 \%}$ acetic acid (HAc; Merck, NJ, USA). A matrix-matched calibration curve was applied for the quantification of HPMA, BMA, and PMA to compensate for the matrix effect. To achieve this, spiked urine samples were used containing $10 \mu \mathrm{L}$ urine, $25 \mu \mathrm{L}$ mixed internal standard (MU-d4 and 2,3 and 4 MHA-d7: $2000 \mathrm{ng} / \mathrm{mL}, 20 \mu \mathrm{L}$ low and high spiked standards (low spike: HPMA, $37.5 \mathrm{ng} / \mathrm{mL}$; PMA, $0.25 \mathrm{ng} / \mathrm{mL}$; MU $5.0 \mathrm{ng} / \mathrm{mL}$, BMA, $1.25 \mathrm{ng} / \mathrm{mL} ; 3+4 \mathrm{MHA}, 20.0 \mathrm{ng} / \mathrm{mL}$; and high spike: HPMA, $75.0 \mathrm{ng} / \mathrm{mL}$ PMA, $0.5 \mathrm{ng} / \mathrm{mL}$; MU, $10.0 \mathrm{ng} / \mathrm{mL}$; BMA, $2.5 \mathrm{ng} / \mathrm{mL} ; 3+4 \mathrm{MHA}, 40.0 \mathrm{ng} / \mathrm{mL}$ (Toronto research chemicals Inc., ON, Canada)) and $445 \mu \mathrm{L} 1 \%$ HAc in ultra-pure water.

Twenty microliters of each sample was injected in an ultra-performance liquid chromatography (UPLS; Waters I-class Acquity UPLC system, Milford, MA, USA)/mass spectrometry (MS; Waters Xevo 
TQ-S tandem in the negative electrospray ionization mode $\left.\left(\mathrm{ESI}^{-}\right)\right)$. An Acquity UPLC ${ }^{\circledR}$ high-strength silica T3 column $\left(50 \mathrm{~mm} \times 2.1 \mathrm{~mm} ; 1.8 \mu \mathrm{m}\right.$; at a constant temperature of $\left.40^{\circ} \mathrm{C}\right)$ with UV detection (Photodiode array (PDA) detector set at $259 \mathrm{~nm}$ ) was used for the simultaneous quantification of the urinary metabolites [38]. Retained compounds were eluted with $4 \mathrm{~mL}$ HAc solution (10\%, v:v). Levels of metabolites were calculated based on the corresponding matrix-matched calibration curve.

\subsubsection{Assessment of Endothelial Function, Carotid Intima Media Thickness, and Retinal} Microvascular Caliber

Vascular endothelial function was assessed via FMD of the right brachial artery, 3-4 cm proximal to the elbow. FMD was measured in the supine position with a mobile Esaote MyLab ${ }^{\mathrm{TM}}$ Five portable ultrasound device (Genoa, Italy) with an Esaote Doppler probe (LA523, $12 \mathrm{MHz}$ ) connected to computerized software with edge detection technology (Quipu Cardiovascular Suite ${ }^{\mathrm{TM}}$; Pisa, Italy) as previously described [24,39]. Briefly, the computerized software determined the mean baseline brachial artery lumen diameter $(\mathrm{mm})$ over a 60 -second period, followed by a 5 -minute ischaemic occlusion (inflation of a manual blood pressure cuff on the forearm to $50 \mathrm{mmHg}$ supra-systolic pressure). Following the 5-minute ischaemic occlusion, deflating the blood pressure cuff triggered reactive hyperaemia and the maximum brachial artery lumen diameter $(\mu \mathrm{m})$ was recorded during this period. The maximum lumen diameter displacement during reactive hyperaemia from the mean baseline measurements was expressed as the percentage of the mean baseline brachial lumen diameter (\% FMD).

The cIMTs of the left and right carotid arteries were determined by B-mode ultrasonography as previously described $[40,41]$. cIMT measurements were performed in the supine position with the head tilted in a $45^{\circ}$ angle upwards. The diameter of carotid intima was determined using an Esaote MyLab $^{\mathrm{TM}}$ Five portable ultrasound device (Genova, Italy) and a B-linear-mode Esaote Doppler probe (LA523, $12 \mathrm{MHz}$, Genoa, Italy) connected to computerized software (RF-QIMT software, Genova, Italy) specific for the determination of carotid metrics. Measurements were taken $5 \mathrm{~mm}$ proximal to the dilation of the carotid bulb. The mean of the left and right carotid diameter and mean of the left and right cIMT were calculated and used for statistical analysis.

Additionally, retinal images were captured with a Canon CR2 digital camera (Canon Europa $\mathrm{NV}$, The Netherlands) and analyzed with semi-automated software (MONA REVA 2.1.1 developed at VITO; https://mona.health) by trained investigators using a standardized protocol as previously described [24]. Briefly, the central retinal arteriolar equivalent (CRAE) of the 6 largest arterioles and the central retinal venular equivalent (CRVE) of the 6 largest venules were determined in the area between 0.5 and 1 disc diameter from the optic disc margin and also expressed as a CRAE/CRVE ratio (AVR). The calculations of the vessel metrics were based on the revised Parr-Hubbard formulas as reported previously [42].

\subsection{Statistical Analysis}

All statistical analyses were performed with IBM $^{\circledR}{ }^{\circledR}$ SPSS $^{\circledR}$ software (version 25 ; New York, NY, USA). Depending on data distribution, a paired sample Student's $t$-test (parametric) or Wilcoxon signed-rank test (non-parametric) was used to identify significant differences between baseline and follow-up visits. A Spearman's Rho correlation (nonparametric data) was used to identify correlations between variables. To determine the association between $\mathrm{NO}_{2}$ or individual BTEX compounds or total BTEX (a summation of all individual BTEX compounds for each participant as a proxy for combined effect of BTEX) and different cardiovascular outcomes, a linear mixed model (LMM) regression analysis was used with participants nested in each visit. Variables with skewed data distribution (BTEX and total BTEX) were log-transformed for regression analysis. To evaluate personal air pollution effects on cardiovascular outcomes independent of potential confounding effects, we selected a priori covariates that are known determinants for cardiovascular outcomes and variables with a potential link with personal air pollution exposure and cardiovascular outcomes. These include age, BMI, 
smoking, socio-economic status (reflected by employment), sleep, and ambient temperature [43-47]. For estimated effects on SBP and DBP, the statistical model included $\mathrm{NO}_{2}$ or BTEX or total BTEX as an exposure variable, participants at each time point as a random effects factor variable with random intercept to account for possible inter-individual variation while adjusting for age, BMI, date of assessment visit, and average temperature as continuous fixed effects and smoking status, employment status, and hours of sleep at night as fixed categorical variables. For effects on other vascular outcomes, we additionally adjusted LMMs for SBP. To determine estimated effects on \% FMD and cIMT, the mean brachial diameter and carotid diameter were additionally adjusted for, respectively. Q-Q plots of the residuals were used to test the assumptions of linearity. The significance threshold was set at $p<0.05$ for all statistical analysis.

\section{Results}

\subsection{Baseline Population Characteristics}

A total number of 77 female participants were recruited for the study. Sixteen participants who completed their baseline visits did not consent to continue with the 6-month follow-up visit and were excluded from the study. A total number of 61 healthy female participants (mean \pm SD age at baseline: $42.5 \pm 13.4$ years) of mixed ancestry completed both assessment visits (Table 1 ).

The majority of participants were current smokers ( $69 \%$; smoking frequency, $<20$ cigarettes/day), but none reported any history of heart or other current serious health problems. Participants were mostly unemployed (49\%). Most participants were overweight with a mean \pm SD BMI of $27.7 \pm 8.4 \mathrm{~kg} / \mathrm{m}^{2}$. Most participants $(n=37 ; 61 \%)$ reported that they sleep 6 to 9 hours per night. The mean \pm SD SBP and DBP values (SBP: $122.5 \pm 19.9) \mathrm{mmHg}$, and DBP: $84.2 \pm 12.0 \mathrm{mmHg}$ ) were within the normal range (Table 2). In total, 11 participants (18\%) presented with hypertension (either SBP of $\geq 140 \mathrm{mmHg}$ or DBP of $\geq 90 \mathrm{mmHg}$ ) at baseline. The median hsCRP level was above the $3 \mathrm{mg} / \mathrm{L}$ cut-off value, and the majority of participants $(n=35 ; 61 \%)$ exhibited elevated hsCRP levels.

Table 1. Baseline study population characteristics $(n=61)$.

\begin{tabular}{|c|c|}
\hline Variable & Baseline \\
\hline Age (years) & $42.5 \pm 13.4$ \\
\hline \multicolumn{2}{|l|}{ Smoking status } \\
\hline Current smoker $(n)$ & $42(69 \%)$ \\
\hline \multicolumn{2}{|l|}{ Employment } \\
\hline Unemployed $(n)$ & $30(49 \%)$ \\
\hline Part-time $(n)$ & $25(41 \%)$ \\
\hline Full-time $(n)$ & $6(10 \%)$ \\
\hline \multicolumn{2}{|l|}{ Hours of sleep per night } \\
\hline$<3 \mathrm{~h}(n)$ & $1(2 \%)$ \\
\hline 3 to $\leq 6 \mathrm{~h}(n)$ & $7(12 \%)$ \\
\hline 6 to $\leq 9 \mathrm{~h}(n)$ & $37(61 \%)$ \\
\hline$>9 \mathrm{~h}(n)$ & $16(25 \%)$ \\
\hline $\mathrm{BMI}, \mathrm{kg} / \mathrm{m}^{3}(n)$ & $27.7 \pm 8.4$ \\
\hline High-sensitivity C-reactive protein $(\mathrm{mg} / \mathrm{L})^{\mathrm{a}, \mathrm{b}}$ & $6.3(0.2$ to 37.1$)$ \\
\hline \multicolumn{2}{|l|}{ Elevated hsCRP $(>3 \mathrm{mg} / \mathrm{L})$} \\
\hline Yes $(n)$ & $35(61 \%)$ \\
\hline No $(n)$ & $22(39 \%)$ \\
\hline Urine creatinine (mmol/L) & $13.5 \pm 7.1$ \\
\hline
\end{tabular}


Table 2. Baseline cardiovascular parameters $(n=61)$.

\begin{tabular}{|c|c|}
\hline Variable & Baseline \\
\hline \multicolumn{2}{|l|}{ Blood pressure } \\
\hline Systolic blood pressure (SBP); mmHg) & $122.5 \pm 19.9$ \\
\hline Diastolic blood pressure (DBP; $\mathrm{mmHg}$ ) & $84.15 \pm 12.0$ \\
\hline Hypertension & \\
\hline \multicolumn{2}{|l|}{ (Either SBP of $>140 \mathrm{mmHg}$ or DBP of $>90 \mathrm{mmHg}$ ) } \\
\hline Yes, $n$ & $15(25 \%)$ \\
\hline No, $n$ & $46(75 \%)$ \\
\hline \multicolumn{2}{|l|}{ Flow-mediated vasodilatation ${ }^{a}$} \\
\hline Brachial diameter $(\mathrm{mm})$ & $3.22 \pm 0.69$ \\
\hline$\%$ Flow-mediated Dilatation (\% FMD) ${ }^{b}$ & 5.21 (-7.93 to 23.50$)$ \\
\hline \multicolumn{2}{|l|}{ Retinal caliber ${ }^{c}$} \\
\hline Central retinal arteriolar equivalent $(\mathrm{CRAE} ; \mu \mathrm{m})$ & $157.9 \pm 16.4$ \\
\hline Central retinal venular equivalent (CRVE; $\mu \mathrm{m})$ & $238.4 \pm 20.1$ \\
\hline CRAE/CRVE ratio (AVR) & $0.66 \pm 0.06$ \\
\hline \multicolumn{2}{|l|}{ Carotid artery } \\
\hline Carotid diameter $(\mathrm{mm})$ & $7.16 \pm 0.84$ \\
\hline Carotid intima media thickness (cIMT; $\mu \mathrm{m})$ & $657.2 \pm 159.3$ \\
\hline
\end{tabular}

Data presented as mean \pm SD or $n(\%){ }^{\text {a }}$ sample size: $n=60{ }^{\text {b }}$ data presented as median (range); ${ }^{\mathrm{c}}$ sample size: $n=58$.

\subsection{Personal Ambient Exposure Variable Outcomes and Urinary Metabolites}

The mean $\mathrm{NO}_{2}$ and median benzene, ethyl-benzene, $\mathrm{m}+\mathrm{p}$-xylene, and o-xylene levels were significantly higher at the baseline visit compared to at the follow-up visit (Table 3). Personal toluene exposure accounted for $\sim 50 \%$ of the total BTEX exposure level at baseline and follow-up visits, while benzene exposure was the lowest at both baseline and follow-up visits. The mean temperature did not differ between baseline and follow-up (Table 3). Strong positive correlations were observed between all personal exposure concentrations $(p<0.001)$ (Table A1). No significant differences in urinary metabolites were observed between baseline and follow-up visits.

Table 3. Air pollution characteristics at baseline and 6-month follow-up $(n=61)$.

\begin{tabular}{|c|c|c|}
\hline Variable & Baseline & Follow-Up \\
\hline Temperature ${ }^{\mathrm{a}, \mathrm{b}}\left({ }^{\circ} \mathrm{C}\right)$ & $21.6 \pm 3.2$ & $21.9 \pm 2.7$ \\
\hline \multicolumn{3}{|c|}{ Personal air pollution measurements } \\
\hline $\mathrm{NO}_{2}{ }^{\mathrm{a}, \mathrm{c}}\left(\mu \mathrm{g} / \mathrm{m}^{3}\right)$ & $13.6 \pm 4.8$ & $10.6 \pm 4.7^{* *}$ \\
\hline Total BTEX ${ }^{c}$ d $\left(\mu \mathrm{g} / \mathrm{m}^{3}\right)$ & 43.0 (12.0 to 327.7$)$ & 34.31 (7.1 to 405.1$)$ \\
\hline Benzene $^{c}\left(\mu \mathrm{g} / \mathrm{m}^{3}\right)$ & $3.9(0.7$ to 14.2$)$ & $2.2(0.5$ to 9.3$) *$ \\
\hline Toluene $^{c}\left(\mu \mathrm{g} / \mathrm{m}^{3}\right)$ & 22.1 (5.6 to 189.2$)$ & $18.0(3.7$ to 284.1$)$ \\
\hline Ethyl-benzene ${ }^{c}\left(\mu \mathrm{g} / \mathrm{m}^{3}\right)$ & $2.8(1.1$ to 34.4$)$ & $2.3(0.7$ to 21.4$) *$ \\
\hline $\mathrm{m}+\mathrm{p}$-xylene ${ }^{\mathrm{c}}\left(\mu \mathrm{g} / \mathrm{m}^{3}\right)$ & $9.2(3.4$ to 117.4$)$ & $7.5(2.0$ to 74.8$) *$ \\
\hline o-xylene ${ }^{c}\left(\mu \mathrm{g} / \mathrm{m}^{3}\right)$ & $3.2(1.2$ to 43.8$)$ & $2.7(0.7$ to 24.7$) *$ \\
\hline \multicolumn{3}{|l|}{ Urinary metabolites ${ }^{\mathrm{e}}$} \\
\hline $\operatorname{HPMA}^{\mathrm{f}}(\mathrm{ng} / \mathrm{mL})$ & 1686 (92 to 12,793$)$ & $1812(120$ to 12,613$)$ \\
\hline PMA $\mathrm{g}(\mathrm{ng} / \mathrm{mL})$ & $0.05(0.05$ to 0.34$)$ & $0.05(0.05$ to 0.34$)$ \\
\hline $\mathrm{MU}^{\mathrm{h}}(\mathrm{ng} / \mathrm{mL})$ & $62.5(62.5$ to 498.0$)$ & $62.5(62.5$ to 595.0$)$ \\
\hline $\mathrm{BMA}^{\mathrm{i}}(\mathrm{ng} / \mathrm{mL})$ & $14.7(2.5$ to 588.0$)$ & $14.3(2.5$ to 699.0$)$ \\
\hline $3+4 \mathrm{MHA}^{\mathrm{j}}(\mathrm{ng} / \mathrm{mL})$ & 1061 (31.8 to 9512.0$)$ & 845 (50.0 to $32,078.0$ ) \\
\hline
\end{tabular}

Data presented as median (range) or ${ }^{\mathrm{a}}$ mean $\pm \mathrm{SD}{ }^{\mathrm{b}}$ the mean represents the average 7-day recorded temperatures (30-minute interval temperature recordings) for each participant prior to the assessment visit, $n=60 .{ }^{\mathrm{c}}$ Values reflect the mean 7-day average during the 7-day period prior to the assessment visit, $n=56$ to 61 . ${ }^{\mathrm{d}}$ Values represent the mean values of the sum of individual BTEX measurements for each participant as a proxy for total BTEX exposure. ${ }^{\mathrm{e}}$ Values of samples below limit of detection (LOD) were replaced by LOD/2. ${ }^{\mathrm{f}}$ Samples concentrations above LOD (>80 ng/mL; baseline/follow-up: $n=61 / 61)$. ' Samples concentrations above LOD (>0.09 ng/mL; baseline/follow-up: $n=10 / 6)$. h Samples concentrations above LOD (>125 ng/mL; baseline/follow-up: $n=14 / 20)$. ${ }^{\mathrm{i}}$ Samples concentrations above LOD $(>5 \mathrm{ng} / \mathrm{mL}$; baseline/follow-up: $n=46 / 45) .{ }^{\mathrm{j}}$ samples concentrations above LOD (>100 ng/mL; baseline/follow-up: $n=60 / 58) .{ }^{*} p<0.05 ; * *<0.01$. 


\subsection{Air Pollution Exposure and Cardiovascular Endpoints}

$\mathrm{NO}_{2}$ exposure was positively associated with blood pressure and negatively associated with blood vessel diameters. Each SD increment $\left(4.96 \mu \mathrm{g} / \mathrm{m}^{3}\right)$ in $\mathrm{NO}_{2}$ was associated with $2.42 \mathrm{mmHg}$ ( $95 \%$ CI: 0.03 to $4.80 \mathrm{mmHg} ; p=0.047$ ) and $1.76 \mathrm{mmHg}$ (95\% CI: 0.00 to $3.52 \mathrm{mmHg} ; p=0.050$ ) increase in SBP and DBP, respectively (Table 4). Each $\mathrm{NO}_{2}$ SD increment was associated with $-2.08 \mu \mathrm{m}(95 \% \mathrm{CI}$ : -4.13 to $-0.02 \mu \mathrm{m} ; p=0.048)$ decrease in CRVE and $-0.11 \mathrm{~mm}(95 \% \mathrm{CI}:-0.19$ to $-0.03 \mathrm{~mm} ; p<0.010)$ decrease in mean baseline brachial diameter.

Table 4. Estimated effects of personal $\mathrm{NO}_{2}$ and total BTEX on vascular outcomes.

\begin{tabular}{|c|c|c|c|}
\hline Variable & Exposure Variable & Estimate $^{\mathrm{a}, \mathrm{b}}(95 \% \mathrm{CI})$ & $p$-Values \\
\hline \multirow[t]{2}{*}{$\mathrm{SBP}^{\mathrm{c}}(\mathrm{mmHg})$} & $\mathrm{NO}_{2}$ & $2.42(0.03 ; 4.80)$ & 0.047 \\
\hline & Total BTEX & $1.54(-1.38 ; 4.46)$ & 0.297 \\
\hline \multirow[t]{2}{*}{$\mathrm{DBP}^{\mathrm{c}}(\mathrm{mmHg})$} & $\mathrm{NO}_{2}$ & $1.76(0.00 ; 3.52)$ & 0.050 \\
\hline & Total BTEX & $2.07(0.06 ; 4.07)$ & 0.043 \\
\hline \multirow[t]{2}{*}{$\operatorname{CRAE}^{\mathrm{d}}(\mu \mathrm{m})$} & $\mathrm{NO}_{2}$ & $-0.47(-2.25 ; 1.31)$ & 0.599 \\
\hline & Total BTEX & $-0.70(-2.88 ; 1.47)$ & 0.521 \\
\hline \multirow[t]{2}{*}{$\operatorname{CRVE}^{\mathrm{d}}(\mu \mathrm{m})$} & $\mathrm{NO}_{2}$ & $-2.08(-4.14 ;-0.02)$ & 0.048 \\
\hline & Total BTEX & $-0.29(-3.00 ; 2.39)$ & 0.829 \\
\hline \multirow[t]{2}{*}{ Mean brachial diameter ${ }^{\mathrm{d}}(\mathrm{mm})$} & $\mathrm{NO}_{2}$ & $-0.11(-0.19 ;-0.03)$ & 0.005 \\
\hline & Total BTEX & $-0.08(-0.17 ; 0.01)$ & 0.090 \\
\hline \multirow[t]{2}{*}{$\% \mathrm{FMD}^{\mathrm{e}}$} & $\mathrm{NO}_{2}$ & $-0.11(-1.00 ; 0.77)$ & 0.801 \\
\hline & Total BTEX & $0.30(-0.56 ; 1.15)$ & 0.492 \\
\hline \multirow[t]{2}{*}{ Carotid Diameter $^{\mathrm{d}}(\mathrm{mm})$} & $\mathrm{NO}_{2}$ & $-0.06(-0.19 ; 0.08)$ & 0.393 \\
\hline & Total BTEX & $-0.12(-0.26 ; 0.02)$ & 0.082 \\
\hline \multirow[t]{2}{*}{$\operatorname{cIMT}^{\mathrm{f}}(\mu \mathrm{m})$} & $\mathrm{NO}_{2}$ & $1.23(-23.63 ; 26.09)$ & 0.921 \\
\hline & Total BTEX & $12.76(-10.55 ; 36.06)$ & 0.275 \\
\hline
\end{tabular}

${ }^{a}$ All models adjusted for date of assessment visit, average temperature, age, body-mass index (BMI), smoking, and employment status (random factor: participant). ${ }^{\mathrm{b}}$ Estimates expressed as a difference in cardiovascular endpoint for each SD increment in exposure. ${ }^{c}$ Additionally adjusted for hours of sleep at night. ${ }^{\mathrm{d}}$ Additionally adjusted for SBP. ${ }^{\text {e }}$ Additionally adjusted for SBP and mean brachial diameter. ${ }^{\mathrm{f}}$ Additionally adjusted for the SBP and carotid diameter.

BTEX exposure was positively associated with blood pressure and cIMT measurements. Each SD increments in total BTEX $\left(2.56 \mu \mathrm{g} / \mathrm{m}^{3}\right)$ and o-xylene $\left(2.51 \mu \mathrm{g} / \mathrm{m}^{3}\right)$ were associated with a $2.07 \mathrm{mmHg}$ (95\% CI: 0.06 to $4.07 \mathrm{mmHg} ; p=0.043$ ) and $2.00 \mathrm{mmHg}$ ( $95 \%$ CI: 0.21 to $3.80 \mathrm{mmHg} ; p=0.029$ ) increase in DBP, respectively (Table 4; and Table A2). Each SD $\left(2.08 \mu \mathrm{g} / \mathrm{m}^{3}\right)$ increment increase in benzene was positively associated with $24.88 \mu \mathrm{m}$ (95\% CI: 2.19 to $47.57 \mu \mathrm{m}) ; p=0.032$ ) increase in cIMT (Table A5).

The urinary metabolite 3+4MHA was negatively associated with vascular function as indicated by $\%$ FMD with an estimated effect of $-1.45 \%$ (95\% CI: $-2.38 \%$ to $-0.51 \% ; p=0.003)$ for each SD $(3.12 \mathrm{ng} / \mathrm{mL})$ increment in 3+4MHA (Table A4). For more detailed results on effects of exposure on vascular outcomes, refer to Tables A2-A5.

\section{Discussion}

The current study set out to determine personal air pollution exposure levels as measured by $\mathrm{NO}_{2}$ and BTEX, in a panel study of female adults residing in the Cape Town region of South Africa, and investigated whether these exposure levels are associated with markers of cardiovascular risk. Major findings of the study are: (1) compared to international air quality standards, our participants' personal exposure to $\mathrm{NO}_{2}$ and BTEX was relatively low, and (2) despite the relatively low exposure levels, we could demonstrate associations between air pollutants and several cardiovascular parameters: SBP and DBP $\left(\mathrm{NO}_{2}\right.$ and BTEX), baseline brachial artery diameter $\left(\mathrm{NO}_{2}\right), \mathrm{CRVE}\left(\mathrm{NO}_{2}\right)$, and cIMT (benzene).

The mean 7-day personal $\mathrm{NO}_{2}$ exposure concentrations (Table 3) observed during the course of the study (range: $2.94 \mu \mathrm{g} / \mathrm{m}^{3}-25.35 \mu \mathrm{g} / \mathrm{m}^{3}$ ) remained below the recommended WHO, European Union (EU) and South African air quality standards for $\mathrm{NO}_{2}$ : annual exposure of $<40 \mu \mathrm{g} / \mathrm{m}^{3}$ and 1-hour 
exposure of $<200 \mu \mathrm{g} / \mathrm{m}^{3}$ [48-51]. At baseline, $24(22 \%)$ of the individual mean benzene measurements (range: $0.475 \mu \mathrm{g} / \mathrm{m}^{3}-14.17 \mu \mathrm{g} / \mathrm{m}^{3}$ ) were higher than WHO and EU annual recommended standards $\left(<5 \mu \mathrm{g} / \mathrm{m}^{3}\right)$, although the median values were below the standards $[17,48]$.

Furthermore, the mean $\mathrm{NO}_{2}$ and median benzene concentrations at baseline in our study population $\left(\mathrm{NO}_{2}: 13.6 \pm 4.8 \mu \mathrm{g} / \mathrm{m}^{3}\right.$ and benzene: $\left.3.22(0.77-14.17) \mu \mathrm{g} / \mathrm{m}^{3}\right)$ were within the lower range of annual mean ambient $\mathrm{NO}_{2}$ and benzene concentrations of major European cities, with $\mathrm{NO}_{2}$ ranging from $8 \mu \mathrm{g} / \mathrm{m}^{3}$ in Stockholm to $43 \mu \mathrm{g} / \mathrm{m}^{3}$ in Barcelona, and benzene ranging between 2 and $12 \mu \mathrm{g} / \mathrm{m}^{3}$ across various cities [3,52-54].

Compared to other studies from the Western Cape Province, the observed mean personal $\mathrm{NO}_{2}$ levels in our study were comparable with recently reported annual mean $\mathrm{NO}_{2}$ levels from air quality monitoring stations in neighboring areas (Goodwood: $21 \mu \mathrm{g} / \mathrm{m}^{3}$; Plattekloof: $10 \mu \mathrm{g} / \mathrm{m}^{3}$ ) [49]. The personal $\mathrm{NO}_{2}$ and individual BTEX concentrations in the current study were furthermore similar to those measured previously (2011-2014) in the Drakenstein sub-district, $\sim 60 \mathrm{~km}$ from the City of Cape Town [55]. In this study, household $\mathrm{NO}_{2}$ and BTEX levels (reported as 2-week median values) were measured in more than 500 homes of families of African and mixed ancestry $\left(\mathrm{NO}_{2}: 7.9\right.$ (Interquartile range (IQR): $3.8-13.3$ ) $\mu \mathrm{g} / \mathrm{m}^{3}$, benzene: 5.6 (IQR: 2.6-17.1) $\mu \mathrm{g} / \mathrm{m}^{3}$, toluene: 19.8 (IQR: 9.3-53.2) $\mu \mathrm{g} / \mathrm{m}^{3}$, ethyl-benzene: 2.1 (IQR: 0.9-53.2) $\mu \mathrm{g} / \mathrm{m}^{3}, \mathrm{~m}+\mathrm{p}$-xylene: $5.8(2.4-16.2) \mu \mathrm{g} / \mathrm{m}^{3}$, and o-xylene 2.4 (IQR: 1.1-7.0) $\left.\mu \mathrm{g} / \mathrm{m}^{3}\right)$.

Ambient outdoor BTEX levels are infrequently measured in the Western Cape Province of South Africa. The Provincial Government Report (2013) reported on BTEX levels (measured with passive samplers) from only two locations in one rural town (Riversdale) in the province [49]. The reported values from Riversdale (two locations with benzene concentrations of 0.89 and $1.05 \mu \mathrm{g} / \mathrm{m}^{3}$, respectively, toluene concentrations of 2.66 and $1.04 \mu \mathrm{g} / \mathrm{m}^{3}$, respectively, ethyl-benzene concentrations of 0.43 and $0.27 \mu \mathrm{g} / \mathrm{m}^{3}$, respectively, and xylene concentrations of 1.82 and $1.19 \mu \mathrm{g} / \mathrm{m}^{3}$, respectively,) were generally lower than the personal BTEX exposure levels measured in our study [49].

Our results showed that personal $\mathrm{NO}_{2}$ and total BTEX (mostly driven by o-xylene) exposure was positively associated with blood pressure outcomes after adjusting for covariates (Table 4). Both long- and short-term exposure to ambient gaseous pollutants has previously been associated with haemodynamic changes including blood pressure, even at low exposure concentrations [18,56-59].

Our findings support those of Chan et al. (2015) who examined the effects of $\mathrm{NO}_{2}$ and fine $\mathrm{PM}$ $\left(\leq 2.5 \mu \mathrm{m} ; \mathrm{PM}_{2.5}\right)$ in a female population and showed that a $10 \mathrm{ppb}$ increase in $\mathrm{NO}_{2}$ was associated with a higher pulse pressure $(0.4 \mathrm{mmHg})$ [60]. In the same study, $\mathrm{PM}_{2.5}$ was also associated with higher SBP (1.4 $\mathrm{mmHg})$, pulse pressure $(1.0 \mathrm{mmHg})$, and mean arterial pressure $(0.8 \mathrm{mmHg})$ [60]. The authors speculated that exposure-associated autonomic dysregulation of vascular tone may be a possible underlying mechanism of their findings $[60,61]$. This may indeed be the case, as our results showed negative associations between $\mathrm{NO}_{2}$ and vessel diameters as indicated by the baseline brachial artery diameter and CRVE. The vasoconstrictive effects of both long-term low-concentrations and short-term high-concentration exposure to ambient air pollution have previously been described $[62,63]$. In the study by Brook et al. (2002), an inverse relationship with brachial artery diameter (ultrasonography) was also demonstrated in 25 healthy adults, although at higher exposure concentrations $\left(150 \mu \mathrm{g} / \mathrm{m}^{3}\right.$ fine $\mathrm{PM}$ and $120 \mathrm{ppb} \mathrm{O}_{3}$ ) and a shorter exposure period ( 2 hour) compared to our exposure concentrations and exposure period [62]. The authors, in a finding similar to ours, failed to demonstrate ambient air pollution exposure-associated effects on FMD [62].

Previous studies have investigated the possible mechanism involved in air pollution exposure-associated vasoconstriction and suggested possible stimulation of the pulmonary vagal afferent neurons and the subsequent increase in sympathetic nervous system reflex activity or an upregulation (directly or via oxidative stress pathways) of vascular endothelin 1 and 3 (vasoconstrictors) [62,64]; however, more studies are required to elucidate the underlying mechanisms. 
Benzene exposure was associated with sub-clinical atherosclerotic changes as measured by cIMT in our study with a relatively large estimated effect on cIMT. cIMT is considered a marker of pro-atherosclerotic processes such as inflammation, a strong predictor of future cardiovascular events [65], and increased cIMT has previously been implicated in long-term ambient PM exposure $[19,66]$. It has also been suggested that women are at higher risk of increased PM-induced cIMT than men [19]. Short-term air pollutant exposure levels in our study were not significantly associated with inflammation (as measured by hsCRP), suggesting that other possible mechanisms may explain the pro-atherosclerotic effects of benzene.

$3+4 \mathrm{MHA}$ appeared to be a prominent urinary metabolite/tracer for exposure in our study as it strongly correlated with all personal exposure levels (Table A1). 3+4MHA is a urinary marker for toluene ( $80 \%$ inhaled toluene metabolized to BMA or MHA) and the primary metabolite for xylene exposure (95\% inhaled xylene metabolized to MHA post-exposure) [38,67-70]. Aside from being a diesel exhaust derivative, xylene is also often used as a solvent in industrial and household products (e.g., adhesives, coatings, degreasers, detergents, dyes, ink, paint, pesticides, polishes, and solvents) [18,56-59].

Xylene is a carcinogen and also associated with central nervous system abnormities such as brain and neurobehavioral morbidities [71,72]. In our study, the positive association between personal total BTEX and DBP was mostly driven by o-xylene, while no adverse associations between BMA (marker of toluene exposure) and vascular endpoints were observed. The significant association between o-xylene and DBP, as well as between its primary urinary metabolite, 3+4MHA (Table A4), and endothelial function suggests that o-xylene may significantly contribute to vascular dysfunction (increased DBP and reduced endothelial function as measured by \% FMD) in our study population. More focused investigations on possible underlying mechanisms are required.

\section{Strengths and Limitations}

The results from the current study are presented with some strengths and limitations. Strengths of current study include the measurement of personal exposure levels, as opposed to levels obtained from centralized air quality monitoring stations in many previous studies from the SSA region. Personal measurements are generally considered a more accurate representation of exposure levels. An additional strength of the study is the fact that we used measurements of different cardiovascular endpoints to investigate physiological effects. To the best of our knowledge, this study is the first to explore the cardiovascular health effects of personal air pollution exposure, in combination with urinary exposure markers, in the South African research setting.

Limitations of the study include a relatively small sample size representing only women, of whom the majority were smokers. The male participant enrolment rate was low, mostly due to employment obligations that resulted in difficulty to attend assessment visits. The high prevalence of smokers in our cohort may be ascribed to the high smoking rates that have previously been reported in the region $[73,74]$. The robust correction for the effects of smoking on various outcomes, based only on smoking status, may not have been optimal. Using levels of biomarkers of smoking such as cotinine may have been a more accurate adjustment for the smoking effect and would have also included the effects of possible second-hand smoke. Personal exposure measurements with a $30 \mathrm{~cm}$ radius extended in front of the face (within the breathing zone) and the inclusion of blank field samples in the study would also have been more desirable. These factors should be considered in future studies. Additionally, as previously shown, the effects of air pollution vary across sex, ethnicity, and health status [75-77]. Our results represent only the exposure effects in an apparently healthy, female population of mixed ancestry and care should be taken to not extrapolate our findings to the general population. 


\section{Conclusions}

Our results show that personal ambient air pollution exposure in women residing in Cape Town, even at relatively low levels, is associated with markers of cardiovascular risk including blood pressure (SBP and DBP), vascular tone/diameter (baseline brachial artery diameter and CRVE), vascular endothelial function (\% FMD), and subclinical atherosclerosis (cIMT).

Author Contributions: Conceptualization, P.D.B., T.S.N., N.G., H.S.; methodology, F.E., P.D.B., T.S.N., N.G., M.M., I.W., D.S.M., N.M., S.C., F.K. and H.S.; software, P.D.B.; validation, F.E., P.D.B., T.S.N., N.G., D.S.M. and H.S.; formal analysis, F.E., P.D.B., T.S.N., D.S.M. and H.S.; investigation, F.E., M.M., I.W., D.S.M., N.M., S.C., F.K. and H.S.; resources, P.D.B., T.S.N., I.W. and H.S.; data curation, F.E., M.M., I.W., N.M., S.C., F.K. and H.S.; writing-original draft preparation, F.E.; writing—review and editing, F.E., P.D.B., T.S.N., N.G., M.M., I.W., D.S.M., N.M., S.C., F.K and H.S.; visualization, F.E.; supervision, P.D.B., T.S.N., N.G. I.W., D.S.M. and H.S.; project administration, F.E., P.D.B., T.S.N., N.G., M.M., I.W. and H.S.; funding acquisition, P.D.B., T.S.N., N.G. and H.S.

Funding: This research was funded by the ERAfrica program of the EU 7th Framework Program (Grant number: IC-003), Department of Science and Technology in South Africa (Grant number: DST/CON 0077/2014), The Belgian Science Policy in Belgium (Grant number BL/67/eranet03), and the Österreichische Agentur für internationale Mobilität und Kooperation in Bildung, Wissenschaft und Forschung, OeAD GmbH (ÖAD) in Austria (Grant number: KEF-Projekt P202). In addition, Frans Everson received a grant from Hasselt University in the context of BILA (bilateral) collaboration with Stellenbosch University (BOF16BL05).

Acknowledgments: We would like to acknowledge Sister Cathy Swartz (Stellenbosch University) for her work with the participants during the course of this study and Griet Jacobs, Samara Fernandes de Souza, Ellen Poelmans, Maarten Spruyt, and Lot Verbeke from the Flemish Institute for Technological Research (VITO; Belgium) for their assistance with sample preparation and quantitative analysis.

Conflicts of Interest: The authors declare no conflict of interest.

\section{Appendix A}
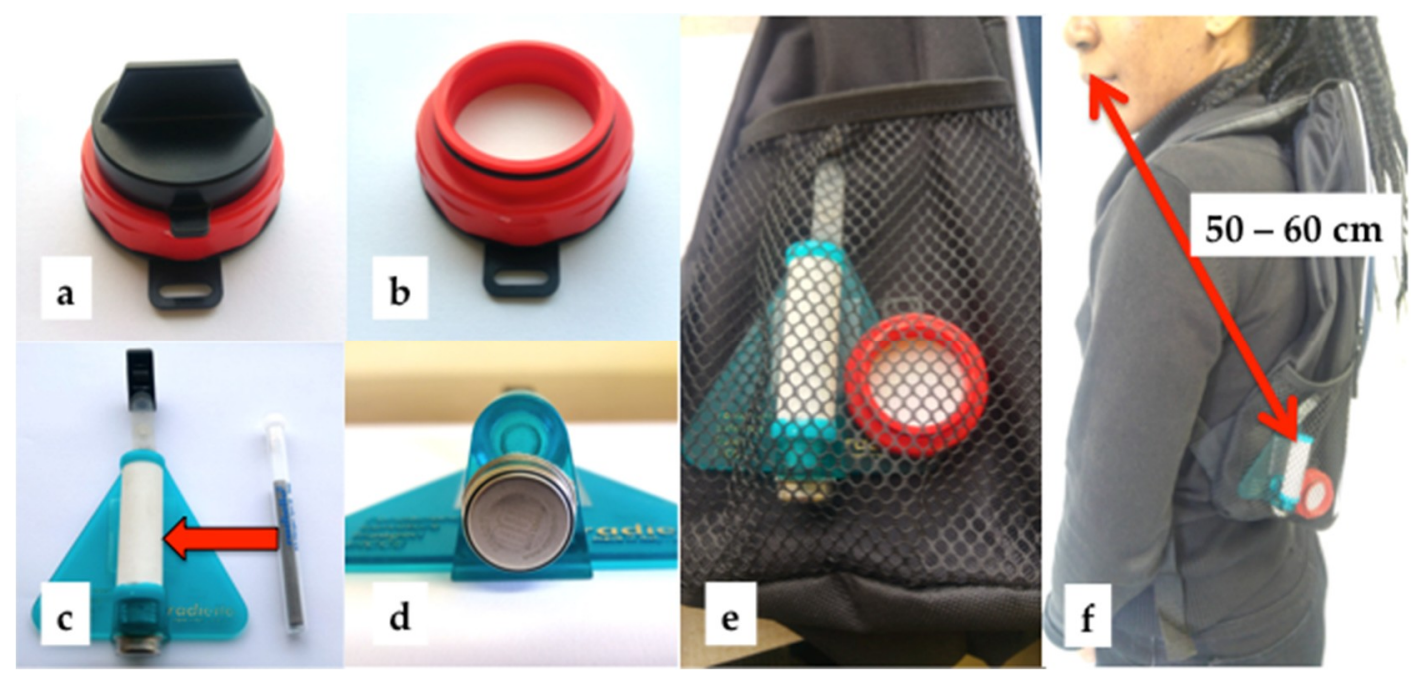

Figure A1. Photos of samplers used for personal exposure measurements: (a) Gradko rapid air $\mathrm{NO}_{2}$ sampler (product: DIFRAM-100; UKAS method: GLM 7; detection limit: $<0.2 \mu \mathrm{g} / \mathrm{m}^{3}$ for 1-week exposure); (b) activated Gradko rapid air $\mathrm{NO}_{2}$ sampler; (c) Radiello ${ }^{\mathrm{TM}}$ diffusive cartridge (right) and diffusive body attached to a triangular support plate (left) (products: Rad130, RAD120, and RAD121; detection limit for BTEX: 0.05, 0.01, 0.01, and $0.01 \mu \mathrm{g} / \mathrm{m}^{3}$, respectively; calibration: $\mathrm{CS}_{2}$ ); (d) ACR Systems Inc. temperature logger (product: SmartButton (01-0187); detection limit: $-40{ }^{\circ} \mathrm{C}$ to $85^{\circ} \mathrm{C}$ ); (e) air monitoring devices in the mesh pocket of a backpack (product: Barron BB0110 Curve and Arch Design backpacks); (f) backpack worn by participants with samplers located 50 to $60 \mathrm{~cm}$ from the face. 
Table A1. Spearman's Rho correlations coefficients $(r)$ for all personal measures of exposure and urinary metabolites.

\begin{tabular}{|c|c|c|c|c|c|c|}
\hline & $\mathrm{NO}_{2}$ & Benzene & Toluene & Ethyl-benzene & $\mathrm{m}+\mathrm{p}$-xylene & o-xylene \\
\hline \multicolumn{7}{|c|}{ Personal Exposure ${ }^{a}$} \\
\hline Benzene & $0.616^{* * *}$ & & & & & \\
\hline Toluene & $0.452 * * *$ & $0.461^{* * *}$ & & & & \\
\hline Ethyl-benzene & $0.622 * * *$ & $0.585^{* * *}$ & $0.652 * * *$ & & & \\
\hline $\mathrm{m}+\mathrm{p}$-xylene & $0.642 * * *$ & $0.595^{* * *}$ & $0.658 * * *$ & $0.983^{* * *}$ & & \\
\hline o-xylene & $0.643^{* * *}$ & $0.589 * * *$ & $0.667^{* * *}$ & $0.972 * * *$ & $0.989^{* * *}$ & \\
\hline Total BTEX ${ }^{b}$ & $0.524^{* * *}$ & $0.474^{* * *}$ & $0.951 * * *$ & $0.790 * * *$ & $0.798^{* * *}$ & $0.808^{* * *}$ \\
\hline \multicolumn{7}{|c|}{ Urinary metabolites $^{c}$} \\
\hline HPMA & 0.081 & $0.186^{*}$ & -0.020 & -0.002 & 0.023 & 0.017 \\
\hline PMA & 0.117 & 0.011 & $-0.218 *$ & -0.112 & -0.105 & -0.123 \\
\hline MU & 0.061 & 0.152 & -0.009 & -0.749 & -0.038 & -0.024 \\
\hline BMA & -0.051 & -0.070 & 0.120 & -0.023 & -0.018 & -0.005 \\
\hline $3+4 \mathrm{MHA}$ & $0.273 * *$ & $0.341^{* * *}$ & $0.218 *$ & $0.192 *$ & $0.215^{*}$ & $0.210 *$ \\
\hline
\end{tabular}

${ }^{\mathrm{a}} n=111$ to $113{ }^{\mathrm{b}}$ values represent the mean values of the sum of individual BTEX measurements for each participant; ${ }^{\mathrm{c}} n=111$ to $121 ;{ }^{*} p<0.05 ;{ }^{* *} p<0.01$; ${ }^{* * *} p<0.001$.

Table A2. Estimated effects of personal $\mathrm{NO}_{2}$, total BTEX, BTEX, and 3+4MHA urinary metabolite on SBP and DBP.

\begin{tabular}{|c|c|c|c|}
\hline Variable & Exposure Variable & Estimate $^{\mathrm{a}, \mathrm{b}}(95 \% \mathrm{CI})$ & $p$-Values \\
\hline \multirow[t]{9}{*}{$\mathrm{SBP}^{\mathrm{c}}(\mathrm{mmHg})$} & $\mathrm{NO}_{2}$ & $2.42(0.03 ; 4.80)$ & 0.047 \\
\hline & Total BTEX & $1.54(-1.38 ; 4.46)$ & 0.297 \\
\hline & Benzene & $2.51(-0.21 ; 5.22)$ & 0.070 \\
\hline & Toluene & $0.92(-2.04 ; 3.88)$ & 0.539 \\
\hline & Ethyl-benzene & $1.44(-1.15 ; 4.03)$ & 0.272 \\
\hline & $\mathrm{m}+\mathrm{p}$-xylene & $1.62(-1.01 ; 4.25)$ & 0.224 \\
\hline & o-Xylene & $2.12(-0.50 ; 4.74)$ & 0.112 \\
\hline & Urinary metabolite ${ }^{\mathrm{d}}$ & & \\
\hline & 3+4MHA & $-0.52(-3.10 ; 2.05)$ & 0.687 \\
\hline \multirow[t]{9}{*}{$\mathrm{DBP}^{\mathrm{c}}(\mathrm{mmHg})$} & $\mathrm{NO}_{2}$ & $1.76(0.00 ; 3.52)$ & 0.050 \\
\hline & Total BTEX & $2.07(0.06 ; 4.07)$ & 0.043 \\
\hline & Benzene & $1.19(-0.73 ; 3.10)$ & 0.220 \\
\hline & Toluene & $1.77(-0.25 ; 3.80)$ & 0.086 \\
\hline & Ethyl-benzene & $1.58(-0.20 ; 3.36)$ & 0.080 \\
\hline & $m+p$-xylene & $1.72(-0.09 ; 3.53)$ & 0.062 \\
\hline & o-xylene & $2.01(0.21 ; 3.80)$ & 0.029 \\
\hline & Urinary metabolite $^{\mathrm{d}}$ & & \\
\hline & $3+4 \mathrm{MHA}$ & $-0.40(-2.28 ; 1.48)$ & 0.673 \\
\hline
\end{tabular}

a All models adjusted for date of assessment visit, average temperature, age, BMI, smoking, and employment status (random factor: participant). ${ }^{\mathrm{b}}$ Estimates expressed as a difference in cardiovascular endpoint for each SD increment in exposure. ${ }^{c}$ Additionally adjusted for hours of sleep at night. ${ }^{\mathrm{d}}$ Additionally adjusted for hours of sleep at night and urine creatinine.

Table A3. Estimated effects of personal $\mathrm{NO}_{2}$, total BTEX, BTEX, and 3+4MHA urinary metabolite on CRAE and CRVE.

\begin{tabular}{clcc}
\hline Variable & \multicolumn{1}{c}{ Exposure Variable } & Estimate $\left.^{\mathbf{a}, \mathbf{b}} \mathbf{( 9 5} \mathbf{9} \mathbf{C I}\right)$ & $p$-Values \\
\hline $\operatorname{CRAE}^{\mathrm{c}}(\mu \mathrm{m})$ & $\mathrm{NO}_{2}$ & $-0.47(-2.25 ; 1.31)$ & 0.599 \\
& Total BTEX & $-0.70(-2.88 ; 1.47)$ & 0.521 \\
& Benzene & $-0.54(-2.51 ; 1.42)$ & 0.582 \\
& Toluene & $-0.74(-2.90 ; 1.43)$ & 0.500 \\
& Ethyl-benzene & $-0.49(-2.24 ; 1.26)$ & 0.579 \\
& m+p-xylene & $-0.60(-2.40 ; 1.21)$ & 0.511 \\
& o-xylene & $-0.68(-2.53 ; 1.16)$ & 0.461 \\
& Urinary metabolite $\mathrm{d}$ & & \\
& 3+4MHA & $-0.57(-2.297 ; 1.167)$ & 0.517 \\
\hline
\end{tabular}


Table A3. Cont.

\begin{tabular}{clcc}
\hline Variable & Exposure Variable & Estimate $\left.^{\mathrm{a}, \mathrm{b}} \mathbf{( 9 5} \mathbf{0} \mathbf{C I}\right)$ & $p$-Values \\
\hline $\mathrm{CRVE}^{\mathrm{c}}(\mu \mathrm{m})$ & $\mathrm{NO}_{2}$ & $-2.08(-4.14 ;-0.02)$ & 0.048 \\
& Total BTEX & $-0.29(-3.00 ; 2.39)$ & 0.829 \\
& Benzene & $-0.67(-3.11 ; 1.78)$ & 0.588 \\
& Toluene & $-0.40(-3.11 ; 2.31)$ & 0.768 \\
& Ethyl-benzene & $-0.53(-2.64 ; 1.58)$ & 0.616 \\
& m+p-xylene & $-0.50(-2.62 ; 1.62)$ & 0.638 \\
& o-xylene & $-0.61(-2.85 ; 1.63)$ & 0.587 \\
& Urinary metabolite ${ }^{\mathrm{d}}$ & & \\
& 3+4MHA & $-0.14(-2.19 ; 1.91)$ & 0.890 \\
\hline
\end{tabular}

a All models adjusted for date of assessment visit, age, BMI, average temperature, smoking, and employment status (random factor: participant). ${ }^{\mathrm{b}}$ Estimates expressed as a difference in cardiovascular endpoint for each SD increment in exposure. ${ }^{c}$ Additionally adjusted for SBP. ${ }^{\mathrm{d}}$ Additionally adjusted for SBP and urine creatinine.

Table A4. Estimated effects of personal $\mathrm{NO}_{2}$, total BTEX, BTEX, and 3+4MHA urinary metabolite on FMD measurements.

\begin{tabular}{|c|c|c|c|}
\hline Variable & Exposure Variable & Estimate $^{\mathrm{a}, \mathrm{b}}(95 \% \mathrm{CI})$ & $p$-Values \\
\hline \multirow[t]{9}{*}{$\begin{array}{c}\text { Mean brachial } \\
\text { diameter }{ }^{c}(\mathrm{~mm})\end{array}$} & $\mathrm{NO}_{2}$ & $-0.11(-0.19 ;-0.03)$ & 0.005 \\
\hline & Total BTEX & $-0.08(-0.17 ; 0.01)$ & 0.090 \\
\hline & Benzene & $-0.01(-0.10 ; 0.08)$ & 0.760 \\
\hline & Toluene & $-0.09(-0.17 ; 0.01)$ & 0.065 \\
\hline & Ethyl-benzene & $-0.08(-0.17 ; 0.00)$ & 0.057 \\
\hline & $\mathrm{m}+\mathrm{p}$-xylene & $-0.06(-0.15 ; 0.02)$ & 0.144 \\
\hline & o-xylene & $-0.06(-0.15 ; 0.03)$ & 0.189 \\
\hline & Urinary metabolite ${ }^{d}$ & & \\
\hline & $3+4 \mathrm{MHA}$ & $0.02(-0.07 ; 0.11)$ & 0.647 \\
\hline \multirow[t]{9}{*}{$\% \mathrm{FMD}^{\mathrm{e}}$} & $\mathrm{NO}_{2}$ & $-0.11(-1.00 ; 0.77)$ & 0.801 \\
\hline & Total BTEX & $0.30(-0.56 ; 1.15)$ & 0.492 \\
\hline & Benzene & $-0.01(-0.87 ; 0.85)$ & 0.982 \\
\hline & Toluene & $0.36(-0.50 ; 1.22)$ & 0.403 \\
\hline & Ethyl-benzene & $0.35(-0.76 ; 0.90)$ & 0.870 \\
\hline & $\mathrm{m}+\mathrm{p}$-xylene & $0.07(-0.77 ; 0.92)$ & 0.862 \\
\hline & o-xylene & $0.16(-0.68 ; 1.00)$ & 0.705 \\
\hline & Urinary metabolite $\mathrm{f}$ & & \\
\hline & 3+4MHA & $-1.45(-2.38 ;-0.51)$ & 0.003 \\
\hline
\end{tabular}

a All models adjusted for date of assessment visit, age, BMI, average temperature, smoking, and employment status (random factor: participant). ${ }^{\mathrm{b}}$ Estimates expressed as a difference in cardiovascular endpoint for each SD increment in exposure. ${ }^{c}$ Additionally adjusted for SBP. ${ }^{\mathrm{d}}$ Additionally adjusted for SBP and urine creatinine. ${ }^{\mathrm{e}}$ Additionally adjusted for SBP and baseline brachial diameter. ${ }^{\mathrm{f}}$ Additionally adjusted for the SBP, baseline brachial diameter, and urine creatinine.

Table A5. Estimated effects of personal $\mathrm{NO}_{2}$, total BTEX, BTEX, and 3+4MHA urinary metabolite on carotid artery measurements.

\begin{tabular}{clcc}
\hline Variable & \multicolumn{1}{c}{ Exposure Variable } & Estimate $^{\mathbf{a}, \mathbf{b}} \mathbf{( 9 5 \% \mathbf { C I } )}$ & $p$-Values \\
\hline $\begin{array}{c}\text { Carotid diameter }^{\mathrm{c}} \\
(\mathrm{mm})\end{array}$ & $\mathrm{NO}_{2}$ & $-0.06(-0.19 ; 0.08)$ & 0.393 \\
& Total BTEX & $-0.12(-0.26 ; 0.02)$ & 0.082 \\
& Benzene & $-0.07(-0.20 ; 0.07)$ & 0.331 \\
& Toluene & $-0.11(-0.25 ; 0.03)$ & 0.132 \\
& Ethyl-benzene & $-0.10(-0.22 ; 0.02)$ & 0.097 \\
& m+p-xylene & $-0.10(-0.23 ; 0.02)$ & 0.109 \\
& o-xylene & $-0.09(-0.22 ; 0.04)$ & 0.156 \\
& Urinary metabolite ${ }^{\mathrm{d}}$ & $-0.07(-0.20 ; 0.07)$ & 0.325 \\
& 3+4MHA &
\end{tabular}


Table A5. Cont.

\begin{tabular}{clcc}
\hline Variable & Exposure Variable & Estimate $\left.^{\text {a,b }} \mathbf{( 9 5 \%} \mathbf{C I}\right)$ & $p$-Values \\
\hline $\operatorname{cIMT}^{\mathrm{e}}(\mu \mathrm{m})$ & $\mathrm{NO}_{2}$ & $1.23(-23.63 ; 26.09)$ & 0.921 \\
& Total BTEX & $12.76(-10.55 ; 36.06)$ & 0.275 \\
& Benzene & $24.88(2.19 ; 47.57)$ & 0.032 \\
& Toluene & $9.37(-13.24 ; 31.99)$ & 0.407 \\
& Ethyl-benzene & $9.10(-14.32 ; 32.52)$ & 0.437 \\
& m+p-xylene & $8.64(-15.36 ; 32.64)$ & 0.471 \\
& o-xylene & $13.06(-10.74 ; 36.85)$ & 0.274 \\
& Urinary metabolite ${ }^{\mathrm{f}}$ & & \\
& 3+4MHA & $-10.56(-30.75 ; 9.63)$ & 0.302 \\
\hline
\end{tabular}

a All models adjusted for date of assessment visit, age, BMI, average temperature, smoking, and employment status (random factor: participant). ${ }^{\mathrm{b}}$ Estimates expressed as a difference in cardiovascular endpoint for each SD increment in exposure. ${ }^{c}$ Additionally adjusted for SBP. ${ }^{\mathrm{d}}$ Additionally adjusted for SBP and urinary creatinine. ${ }^{\mathrm{e}}$ Additionally adjusted for SBP and mean brachial diameter. ${ }^{\mathrm{f}}$ Additionally adjusted for the SBP, mean carotid diameter, and urinary creatinine.

\section{References}

1. Kampa, M.; Castanas, E. Human health effects of air pollution. Environ. Pollut. 2008, 151, 362-367. [CrossRef] [PubMed]

2. Zhang, J.; Smith, K.R. Indoor air pollution: A global health concern. Br. Med. Bull. 2003, 68, 209-225. [CrossRef] [PubMed]

3. World Health Organization: Regional Office for Europe. WHO Guidelines for Indoor Air Quality: Selected Pollutants. Available online: https://afro.who.int/publications/selected-pollutants-who-guideline-indoor-airquality (accessed on 18 February 2019).

4. Meng, Q.; Richmond-Bryant, J.; Lu, S.E.; Buckley, B.; Welsh, W.J.; Whitsel, E.A.; Hanna, A.; Yeatts, K.B.; Warren, J.; Herring, A.H.; et al. Cardiovascular outcomes and the physical and chemical properties of metal ions found in particulate matter air pollution: A QICAR study. Environ. Health Perspect. 2013, 121, 558-564. [CrossRef] [PubMed]

5. Bourdrel, T.; Bind, M.-A.; Béjot, Y.; Morel, O.; Argacha, J.-F. Cardiovascular effects of air pollution. Arch. Cardiovasc. Dis. 2017, 110, 634-642. [CrossRef] [PubMed]

6. Mills, N.L.; Donaldson, K.; Hadoke, P.W.; Boon, N.A.; MacNee, W.; Cassee, F.R.; Sandstrom, T.; Blomberg, A.; Newby, D.E. Adverse cardiovascular effects of air pollution. Nat. Clin. Pract. Cardiovasc. Med. 2009, 6, 36-44. [CrossRef] [PubMed]

7. Mills, N.L.; Miller, M.R.; Lucking, A.J.; Beveridge, J.; Flint, L.; Boere, A.J.F.; Fokkens, P.H.; Boon, N.A.; Sandstrom, T.; Blomberg, A.; et al. Combustion-derived nanoparticulate induces the adverse vascular effects of diesel exhaust inhalation. Eur. Heart J. 2011, 32, 2660-2671. [CrossRef] [PubMed]

8. Künzli, N.; Tager, I.B. Air pollution: From lung to heart. Swiss Med. Wkly. 2005, 135, 697-702. [PubMed]

9. Kelly, F.J.; Fussell, J.C. Role of oxidative stress in cardiovascular disease outcomes following exposure to ambient air pollution. Free Radic. Biol. Med. 2017, 110, 345-367. [CrossRef]

10. Brook, R.D.; Rajagopalan, S.; Pope, C.A.; Brook, J.R.; Bhatnagar, A.; Diez-Roux, A.V.; Holguin, F.; Hong, Y.; Luepker, R.V.; Mittleman, M.A.; et al. Particulate matter air pollution and cardiovascular disease: An update to the scientific statement from the american heart association. Circulation 2010, 121, 2331-2378. [CrossRef] [PubMed]

11. Nelin, T.D.; Joseph, A.M.; Gorr, M.W.; Wold, L.E. Direct and indirect effects of particulate matter on the cardiovascular system. Toxicol. Lett. 2012, 208, 293-299. [CrossRef] [PubMed]

12. Bernstein, J.A.; Alexis, N.; Barnes, C.; Bernstein, I.L.; Bernstein, J.A.; Nel, A.; Peden, D.; Diaz-Sanchez, D.; Tarlo, S.M.; Williams, P.B. Health effects of air pollution. J. Allergy Clin. Immunol. 2004, 114, 1116-1123. [CrossRef] [PubMed]

13. Mannucci, P.M.; Harari, S.; Martinelli, I.; Franchini, M. Effects on health of air pollution: A narrative review. Intern. Emerg. Med. 2015, 10, 657-662. [CrossRef] [PubMed]

14. Łatka, P.; Nowakowska, D.; Nowomiejska, K.; Rejdak, R. How air pollution affects the eyes-A review. Ophthalmol. J. 2018, 3, 58-62. [CrossRef] 
15. Collart, P.; Dubourg, D.; Levêque, A.; Sierra, N.B.; Coppieters, Y. Short-term effects of nitrogen dioxide on hospital admissions for cardiovascular disease in Wallonia, Belgium. Int. J. Cardiol. 2018, 255, 231-236. [CrossRef] [PubMed]

16. Miri, M.; Rostami Aghdam Shendi, M.; Ghaffari, H.R.; Ebrahimi Aval, H.; Ahmadi, E.; Taban, E.; Gholizadeh, A.; Yazdani Aval, M.; Mohammadi, A.; Azari, A. Investigation of outdoor BTEX: Concentration, variations, sources, spatial distribution, and risk assessment. Chemosphere 2016, 163, 601-609. [CrossRef] [PubMed]

17. World Health Organization. Ambient Air Pollution: A Global Assessment of Exposure and Burden of Disease. Available online: https:/www.who.int/phe/publications/air-pollution-global-assessment/en/ (accessed on 15 March 2019).

18. Bolden, A.L.; Kwiatkowski, C.F.; Colborn, T. New look at BTEX: Are ambient levels a problem. Environ. Sci. Technol. 2015, 49, 5261-5276. [CrossRef]

19. Autrup, H. Ambient air pollution and adverse health effects. Procedia Soc. Behav. Sci. 2010, 2, 7333-7338. [CrossRef]

20. Smith, K.R.; Mehta, S. The burden of disease from indoor air pollution in developing countries: Comparison of estimates. Int. J. Hyg. Environ. Health 2003, 206, 279-289. [CrossRef]

21. Cohen, A.J.; Anderson, H.R.; Ostro, B.; Pandey, K.D.; Künzli, N.; Gutschmidt, K.; Pope, A.; Samet, J.M.; Smith, K. The global burden of disease due to outdoor air pollution. J. Toxicol. Environ. Health 2006, 68, 1301-1307. [CrossRef]

22. Coker, E.; Kizito, S.; Coker, E.; Kizito, S. A narrative review on the human health effects of ambient air pollution in Sub-Saharan Africa: An urgent need for health effects studies. Int. J. Environ. Res. Public Health 2018, 15, 427. [CrossRef]

23. Katoto, P.D.M.C.; Byamungu, L.; Brand, A.S.; Mokaya, J.; Strijdom, H.; Goswami, N.; De Boever, P.; Nawrot, T.S.; Nemery, B. Ambient air pollution and health in Sub-Saharan Africa: Current evidence, perspectives and a call to action. Environ. Res. 2019, 173, 174-188. [CrossRef] [PubMed]

24. Strijdom, H.; De Boever, P.; Walzl, G.; Essop, M.F.; Nawrot, T.S.; Webster, I.; Westcott, C.; Mashele, N.; Everson, F.; Malherbe, S.T.; et al. Cardiovascular risk and endothelial function in people living with HIV/AIDS: Design of the multi-site, longitudinal EndoAfrica study in the Western Cape Province of South Africa. BMC Infect. Dis. 2017, 17, 1-9. [CrossRef] [PubMed]

25. Grammer, L.C.; Harris, K.E.; Yarnold, P.R. Effect of Respiratory Protective Devices on Development of Antibody and Occupational Asthma to an Acid Anhydride. Chest 2002, 121, 1317-1322. [CrossRef] [PubMed]

26. Rodes, C.E.; Lawless, P.A.; Evans, G.F.; Sheldon, L.S.; Williams, R.W.; Vette, A.F.; Creason, J.P.; Walsh, D. The relationships between personal PM exposures for elderly populations and indoor and outdoor concentrations for three retirement center scenarios. J. Expo. Anal. Environ. Epidemiol. 2001, 11, 103-115. [CrossRef] [PubMed]

27. Targa, J.; Loader, A. Diffusion Tubes for Ambient $\mathrm{NO}_{2}$ Monitoring: Practical Guidance for Laboratories and Users. Available online: https:/uk-air.defra.gov.uk/assets/documents/reports/cat05/0802141004_NO2_WG_ PracticalGuidance_Issue1a.pdf (accessed on 6 March 2019).

28. Palmes, E.D.; Gunnison, A.F.; Dimattio, J.; Tomczyk, C. Personal sampler for nitrogen dioxide. Am. Ind. Hyg. Assoc. J. 1976, 37, 570-577. [CrossRef] [PubMed]

29. Akdemir, A. The creation of pollution mapping and measurement of ambient concentration of sulfur dioxide and nitrogen dioxide with passive sampler. J. Environ. Heal. Sci. Eng. 2014, 12, 1-9. [CrossRef] [PubMed]

30. McAlary, T.; Groenevelt, H.; Disher, S.; Arnold, J.; Seethapathy, S.; Sacco, P.; Crump, D.; Schumacher, B.; Hayes, H.; Johnson, P.; et al. Passive sampling for volatile organic compounds in indoor air-controlled laboratory comparison of four sampler types. Environ. Sci. Process. Impacts 2015, 17, 896-905. [CrossRef]

31. Pegas, P.N.; Alves, C.A.; Evtyugina, M.G.; Nunes, T.; Cerqueira, M.; Franchi, M.; Pio, C.A.; Almeida, S.M.; Freitas, M.C. Indoor air quality in elementary schools of Lisbon in spring. Environ. Geochem. Health 2011, 33, 455-468. [CrossRef]

32. Seedat, Y.K.; Rayner, B.L. The abridged South African hypertension guideline 2011. S. Afr. Fam. Pract. 2013, 55, 111-116. [CrossRef]

33. Ridker, P.M. From C-reactive protein to interleukin-6 to interleukin-1: Moving upstream to identify novel targets for atheroprotection. Circ. Res. 2016, 118, 145-156. [CrossRef] 
34. Stevens, J.F.; Maier, C.S. Acrolein: Sources, metabolism, and biomolecular interactions relevant to human health and disease. Mol. Nutr. Food Res. 2008, 52, 7-25. [CrossRef] [PubMed]

35. Qu, Q.; Shore, R.; Li, G.; Su, L.; Jin, X.; Melikian, A.A.; Roy, N.; Chen, L.C.; Wirgin, I.; Cohen, B.; et al. Biomarkers of benzene: Urinary metabolites in relation to individual genotype and personal exposure. Chem. Biol. Interact. 2005, 153-154, 85-95. [CrossRef] [PubMed]

36. Angerer, J.; Schildbach, M.; Krämer, A. Sp-Toluylmercapturic acid in the urine of workers exposed to toluene: A new biomarker for toluene exposure. Arch. Toxicol. 1997, 72, 119-123. [CrossRef]

37. Jacobson, G.A.; McLean, S. Biological Monitoring of Low Level Occupational Xylene Exposure and the Role of Recent Exposure. Ann. Occup. Hyg. 2003, 47, 331-336. [PubMed]

38. Pirkle, J.L.; De Jesus, V. Laboratory Procedure Manual: Volatile Organic Compounds (VOCs): Urine Ultra Performance Liquid Chromatography with Electro Spray Tandem Mass Spectrometry. Available online: https: //wwwn.cdc.gov/nchs/data/nhanes/2011-2012/labmethods/UVOC_G_MET_VOC_Metabolites.pdf (accessed on 6 June 2019).

39. Charakida, M.; Masi, S.; Luscher, T.F.; Kastelein, J.J.P.; Deanfield, J.E. Assessment of atherosclerosis: The role of flow-mediated dilatation. Eur. Heart J. 2010, 31, 2854-2861. [CrossRef] [PubMed]

40. Simova, I. Intima-Media Thickness: Appropriate Evaluation and Proper Measurement, Described. Available online: https://www.escardio.org/Journals/E-Journal-of-Cardiology-Practice/Volume-13/Intimamedia-thickness-Appropriate-evaluation-and-proper-measurement-described (accessed on 20 April 2019).

41. Mendonça, J.A.; Bisetto de Andrade, B.; Braga de Aquino, J.L.; Leandro-Merhi, V.A.; Damian, G.B.; De Andrade, B.B.; De Aquino, J.L.B.; Leandro-Merhi, V.A.; Damian, G.B. Spectral Doppler and automated software-guided ultrasound assessment of bilateral common carotid intima-media thickness in spondyloarthritis: Is there a correlation with clinical findings? Drugs Context 2018, 7, 1-9. [CrossRef] [PubMed]

42. Knudtson, M.D.; Lee, K.E.; Hubbard, L.D.; Wong, T.Y.; Klein, R.; Klein, B.E.K. Revised formulas for summarizing retinal vessel diameters. Curr. Eye Res. 2003, 27, 143-149. [CrossRef] [PubMed]

43. Langham, M.C.; Zhou, Y.; Chirico, E.N.; Magland, J.F.; Sehgal, C.M.; Englund, E.K.; Mohler, E.R.; Guo, W.; Barhoum, S.; Wehrli, F.W. Effects of age and smoking on endothelial function assessed by quantitative cardiovascular magnetic resonance in the peripheral and central vasculature. J. Cardiovasc. Magn. Reson. 2015, 17, 19. [CrossRef]

44. Huxley, R.; Mendis, S.; Zheleznyakov, E.; Reddy, S.; Chan, J. Body mass index, waist circumference and waist:hip ratio as predictors of cardiovascular risk-A review of the literature. Eur. J. Clin. Nutr. 2009, 64, 16-22. [CrossRef]

45. Jerrett, M.; Burnett, R.T.; Brook, J.; Kanaroglou, P.; Giovis, C.; Finkelstein, N.; Hutchison, B. Do socioeconomic characteristics modify the short term association between air pollution and mortality? Evidence from a zonal time series in Hamilton, Canada. J. Epidemiol. Community Health 2004, 58, 31-40. [CrossRef]

46. Kakkoura, M.; Kouis, P.; Papatheodorou, S.I.; Paschalidou, A.K.; Ziogas, K.; Kakkoura, M.; Ziogas, K.; Paschalidou, A.K.; Papatheodorou, S.I. The effect of ambient air temperature on cardiovascular and respiratory mortality in Thessaloniki, Greece. Sci. Total Environ. 2018, 647, 1351-1358.

47. Watson, N.F.; Badr, M.S.; Belenky, G.; Bliwise, D.L.; Buxton, O.M.; Buysse, D.; Dinges, D.F.; Gangwisch, J.; Grandner, M.A.; Kushida, C.; et al. Recommended Amount of Sleep for a Healthy Adult: A Joint Consensus Statement of the American Academy of Sleep Medicine and Sleep Research Society. J. Clin. Sleep Med. 2015, 11, 591-592. [PubMed]

48. European Environment Agency. Air Quality in Europe-2018 Report. Available online: http://www.eea. europa.eu/publications/air-quality-in-europe-2012 (accessed on 25 March 2019).

49. South African Western Cape Government. Western Cape State of air Quality Management Report: 2013. Available online: https://www.westerncape.gov.za/eadp/files/atoms/files/SoAR2014.pdf (accessed on 25 March 2019).

50. World Health Organization. World Health Organization Guidelines for Indoor Air Quality: Household Fuel Combustion. Available online: http://www.who.int/indoorair/guidelines/hhfc/HHFC_guidelines.pdf (accessed on 25 March 2019).

51. Davidson, A.; Naidoo, D. State of Environment Outlook Report for the Western Cape Province-Air Quality. Available online: http://eadp.westerncape.gov.za/sites/default/files/your-resource-library/WCSoEOR_07_ ClimateChange.pdf (accessed on 25 March 2019). 
52. Degraeuwe, B.; Thunis, P.; Clappier, A.; Weiss, M.; Lefebvre, W.; Janssen, S.; Vranckx, S. Impact of passenger car NOX emissions on urban NO2 pollution-Scenario analysis for 8 European cities. Atmos. Environ. 2017, 171, 330-337. [CrossRef]

53. Kuklinska, K.; Wolska, L.; Namiesnik, J. Air quality policy in the U.S. and the EU-A review. Atmos. Pollut. Res. 2014, 6, 129-137. [CrossRef]

54. World Health Organization. WHO Air Quality Guidelines for Europe, 2nd ed.; Available online: https: //apps.who.int/iris/handle/10665/107335 (accessed on 25 March 2019).

55. Vanker, A.; Barnett, W.; Nduru, P.M.; Gie, R.P.; Sly, P.D.; Zar, H.J. Home environment and indoor air pollution exposure in an African birth cohort study. Sci. Total Environ. 2015, 536, 362-367. [CrossRef] [PubMed]

56. Franchini, M.; Mannucci, P.M. Air pollution and cardiovascular disease. Thromb. Res. 2012, 129, $230-234$. [CrossRef] [PubMed]

57. Hoffmann, B.; Luttmann-Gibson, H.; Cohen, A.; Zanobetti, A.; de Souza, C.; Foley, C.; Suh, H.H.; Coull, B.A.; Schwartz, J.; Mittleman, M.; et al. Opposing effects of particle pollution, ozone, and ambient temperature on arterial blood pressure. Environ. Health Perspect. 2012, 120, 241-246. [CrossRef] [PubMed]

58. Weichenthal, S.; Hatzopoulou, M.; Goldberg, M.S. Exposure to traffic-related air pollution during physical activity and acute changes in blood pressure, autonomic and micro-vascular function in women: A cross-over study. Part. Fibre Toxicol. 2014, 11, 70. [CrossRef]

59. Yang, B.; Qian, Z.; Howard, S.W.; Vaughn, M.G.; Fan, S.; Liu, K.; Dong, G. Global association between ambient air pollution and blood pressure: A systematic review and meta-analysis. Environ. Pollut. 2018, 235, 576-588. [CrossRef]

60. Chan, S.H.; Van Hee, V.C.; Bergen, S.; Szpiro, A.A.; DeRoo, L.A.; London, S.J.; Marshall, J.D.; Kaufman, J.D.; Sandler, D.P.; Kaufman, J.D.; et al. Long-term air pollution exposure and blood pressure in the sister study. Environ. Health Perspect. 2015, 123, 951-958. [CrossRef]

61. Chen, J.-C.; Wang, X.; Wellenius, G.A.; Serre, M.L.; Driscoll, I.; Casanova, R.; McArdle, J.J.; Manson, J.E.; Chui, H.C.; Espeland, M.A. Ambient air pollution and neurotoxicity on brain structure: Evidence from women's health initiative memory study. Ann. Neurol. 2015, 78, 466-476. [CrossRef] [PubMed]

62. Brook, R.D.; Brook, J.R.; Urch, B.; Vincent, R.; Rajagopalan, S.; Silverman, F. Inhalation of fine particulate air pollution and ozone causes acute arterial vasoconstriction in healthy adults. Circulation 2002, 105, 1534-1536. [CrossRef] [PubMed]

63. Adar, S.D.; Klein, R.; Klein, B.E.K.; Szpiro, A.A.; Cotch, M.F.; Wong, T.Y.; O’Neill, M.S.; Shrager, S.; Barr, R.G.; Siscovick, D.S.; et al. Air pollution and the microvasculature: A cross-sectional assessment of in vivo retinal images in the population-based multi-ethnic study of atherosclerosis (MESA). PLoS Med. 2010, 7, e1000372. [CrossRef] [PubMed]

64. Langrish, J.P.; Lundbäck, M.; Mills, N.L.; Johnston, N.R.; Webb, D.J.; Sandström, T.; Blomberg, A.; Newby, D.E.; Sandström, T.; Lundbäck, M.; et al. Contribution of endothelin 1 to the vascular effects of diesel exhaust inhalation in humans. Hypertension 2009, 54, 910-915. [CrossRef] [PubMed]

65. Bots, M.L.; Hoes, A.W.; Koudstaal, P.J.; Hofman, A.; Grobbee, D.E. Common carotid intima-media thickness and risk of stroke and myocardial infarction: The Rotterdam Study. Circulation 1997, 96, 1432-1437. [CrossRef] [PubMed]

66. Sheppard, L.; Watson, K.; Budoff, M.; Sampson, P.D.; Barr, R.G.; Diez Roux, A.V.; Jacobs, D.R.; Kaufman, J.D.; Vedal, S.; Polak, J.F.; et al. Fine particulate air pollution and the progression of carotid intima-medial thickness: A prospective cohort study from the Multi-Ethnic Study of Atherosclerosis and Air Pollution. PLoS Med. 2014, 10, e1001430.

67. Corn, M. Handbook of Hazardous Materials; Elsevier Science: Amsterdam, The Netherlands, 1993; ISBN 0323139558.

68. Interaction Profile For: Benzene, Toluene, Ethylbenzene, and Xylenes (BTEX). Available online: https://pdfs.semanticscholar.org/3ad5/8812c08fd4d51c7652eff236c5a88be8444a.pdf?_ga=2.123559363. 973190570.1527186213-1785467536.1527186213 (accessed on 24 May 2019).

69. Hormozi, M.; Mirzaei, R.; Nakhaee, A.; Payandeh, A.; Izadi, S.; Dehghan Haghighi, J.; Rahimpoor, R. Quantification of urinary metabolites of toluene and xylene isomers as biological indices of occupational exposure in printing industry workers. Heal. Scope 2019, in press. [CrossRef]

70. Langman, J.M. Xylene: Its toxicity, measurement of exposure levels, absorption, metabolism and clearance. Pathology 1994, 26, 301-309. [CrossRef] 
71. Bolla, K.I.; Schwartz, B.S.; Stewart, W.; Rignani, J.; Agnew, J.; Ford, D.P. Comparison of neurobehavioral function in workers exposed to a mixture of organic and inorganic lead and in workers exposed to solvents. Am. J. Ind. Med. 1995, 27, 231-246. [CrossRef]

72. Celik, A.; Aydin, N.; Ozcirpici, B.; Saricicek, E.; Sezen, H.; Okumus, M.; Bozkurt, S.; Kilinc, M. Elevated red blood cell distribution width and inflammation in printing workers. Med. Sci. Monit. 2013, 19, 1001-1005.

73. Croxford, J.; Viljoen, D. Alcohol consuption by pregnant women in the Western Cape. SAMJ 1999, 89, 962-965. [PubMed]

74. Reddy, P.; Zuma, K.; Shisana, O.; Kim, J.; Sewpaul, R.; Jonas, K.; Sewpaul, R. Prevalence of tobacco use among adults in South Africa: Results from the first South African national health and Nutrition Examination Survey. S. Afr. Med. J. 2015, 105, 648-655. [CrossRef] [PubMed]

75. Oliveira, A.R.; Campos Neto, A.A.; de Andrade, M.J.O.; de Medeiros, P.C.B.; dos Santos, N.A. Organic solvent exposure and contrast sensitivity: Comparing men and women. Braz. J. Med. Biol. Res. 2018, 51, e6568. [CrossRef] [PubMed]

76. O'Neill, M.S.; Breton, C.V.; Devlin, R.B.; Utell, M.J. Air pollution and health: Emerging information on susceptible populations. Air Qual. Atmos. Heal. 2012, 5, 189-201. [CrossRef] [PubMed]

77. Walton, R.T.; Mudway, I.S.; Dundas, I.; Grigg, J.; Marlin, N.; Koh, L.C.; Aitlhadj, L.; Vulliamy, T.; Jamaludin, J.B.; Wood, H.E.; et al. Air pollution, ethnicity and telomere length in east London schoolchildren: An observational study. Environ. Int. 2016, 96, 41-47. [CrossRef] [PubMed]

(C) 2019 by the authors. Licensee MDPI, Basel, Switzerland. This article is an open access article distributed under the terms and conditions of the Creative Commons Attribution (CC BY) license (http://creativecommons.org/licenses/by/4.0/). 